\title{
INITIATIVES TO OVERCOME SOCIAL INEQUALITIES IN PUBLIC HEALTH MANAGEMENT IN THE EUROPEAN UNION
}

doi: 10.2478/cqpi-2019-0011

Date of submission of the article to the Editor: 21/04/2019

Date of acceptance of the article by the Editor: 18/05/2019

\author{
Magdalena Bsoul - Kopowska - orcid id: 0000-0002-6167-6827 \\ Czestochowa University of Technology, Poland
}

\begin{abstract}
This paper focuses on the methods to reduce social inequalities through appropriate public health management implemented within the EU. In the initiatives taken by the EU, it is important to contribute to the achievement of greater equality in terms of health in all social groups in the member states, and to reduce heterogeneity between countries in combating health inequalities by focusing on their socioeconomic determinants related to health and lifestyles. The research method adopted in this paper was the analysis of documents related to direct actions on health safety and health policy within the European Union.
\end{abstract}

Keywords: public health management, health safety, EU health policy

\section{INTRODUCTION}

Public health issues were explicitly addressed for the first time in the Treaty on European Union, which was signed in Maastricht in 1992 and then in the 1999 Treaty of Amsterdam. However, it was the Treaty of Lisbon signed in 2007 that substantially enhanced the importance of health policy in the activities of the European Union, stating that "a high level of human health protection shall be ensured in the definition and implementation of all Community policies and activities" (https:// europa. eu/european-union/topics/health_en). This objective was to be achieved through community support to member states and through closer cooperation. It is worth noting at this point that in European Union policy, the primary responsibility for health care, and especially for health care systems continues to lie with the Member States, whereas the role of the EU is primarily to complement and support the activities carried out in individual countries, where coordination, cooperation and exchange of knowledge, information and best practices are the best means of achieving good results. Therefore, the European Union plays an important role in improving public health, preventing and treatment of diseases, reducing the number of sources of hazards to human health, and alignment of health strategies between member states (http://eur-lex.europa.eu/legal-content/PL/TXT/?uri= CELE X\%3A12016E168).

In the Rome Declaration signed on the occasion of the 60th anniversary of the construction of European unity on 25 March 2017, the leaders of the European Union 
declared that: "We want a Union where citizens have new opportunities for cultural and social development and economic growth (...) The last six decades of European integration have brought many new opportunities for development for all citizens and raised social standards in each of the Member States. Despite these enormous achievements, major societal challenges persist across Europe. The economic crisis has left deep traces in the lives of individuals and entire societies. It raised doubts as to whether the benefits and challenges of opening up markets and societies and emerging innovation and technological changes are fairly distributed. The crisis has undermined confidence in Europe's ability to influence its future and create fair and prosperous societies. By achieving the ambitious social objectives that we share in Europe, we can rebuild public support and, at the same time, take responsibility for our future in our own hands" (https://ec.europa.eu/commission/sites/beta-political /files/reflection-paper-social-dimension-europe_en.pdf)

The rationale behind writing this paper is the growing importance of health safety management in EU policies, which is reflected, among other things, in actions aimed at reducing social inequalities. It should be noted that there are significant health inequalities both between individual EU countries and between different groups of people in these countries. To a large extent, this is due to social determinants that affect life expectancy and overall health status. These social determinants include employment, wages, education level and ethnicity. In order to eliminate health inequalities, the EU promotes appropriate policies and helps national authorities and stakeholders to take measures to reduce these inequalities.

The aim of this paper is to present EU activities concerning the methods of elimination of social inequalities through appropriate public health management within the EU, which aims to contribute to achieving greater equality in terms of health in all social groups within each member state and to reduce heterogeneity between countries in combating health inequalities by focusing on the socio-economic determinants of health and lifestyles.

\section{SELECTED INITIATIVES OF THE EUROPEAN UNION IN PUBLIC HEALTH MANAGEMENT}

The 2009 Communication from the European Commission "Solidarity in health: Reducing health inequalities in the EU" sets out an initial strategy for this area, which includes, among other things, the assessment of the impact of EU policies on health inequalities; updating data on health inequalities and effective strategies to reduce them; and information on EU funding to help national authorities and other bodies address health inequalities (https://ec.europa.eu/health/social).

The strategy aims both to support policy development in EU countries and to increase the contribution of EU policies to reducing health inequalities. The main challenges of this strategy include reducing health differences in overall social and economic development; improvement of data resources and knowledge base; building social engagement; addressing the needs of vulnerable groups and increasing the contribution of EU policies.

In 2013, the Commission has published a working document called Report on health inequalities in the European Union which provides information and figures on health inequalities in the EU. The report draws attention to: ensuring decent working conditions in all forms of employment, introducing measures to facilitate work-life 
balance and combating child poverty. The detailed results of this Report will be presented later in this paper.

Considering that the level of public health depends on factors such as daily living conditions, unemployment, income and education level, the EU is also taking a number of measures to strengthen the labour market. An example is the Europe 2020 Strategy, which is a long-term plan to ensure that $75 \%$ of people aged from 20 to 64 years will be employed. It also helps its citizens to look for work across Europe by working with the EURES network of advisers who are in everyday contact with jobseekers and employers. In addition, the EU also co-finances skills development programmes, e.g. through the European Social Fund.

The European Globalisation Adjustment Fund (EGF) was set up to support workers who have been made redundant as a result of changing trends in the world economy (e.g. closing of enterprises or relocation of production outside the EU). The EU is working on new regulations for the period after the year 2020 to make the fund more accessible and adapted to the challenges of digitisation and environmental change.

Furthermore, there is also the European Job Mobility Portal (EURES). It represents a job mobility network that provides information and guidance and recruitment/job placement services for employers and jobseekers. In 2016, the European Parliament adopted new legislation reorganising the EURES portal to better match supply and demand in the labour market.

To combat youth unemployment, EU member states decided in 2013 to launch the Youth Guarantee, an EU initiative that provides all young people under the age of 25 years with a good quality offer of employment, continued education, vocational training or apprenticeship within a period of four months of becoming unemployed or leaving formal education.

In April 2017, the European Commission presented a draft of the European Pillar of Social Rights. Its aim is to support fair and efficient labour markets and social protection systems. This pillar is based on 20 main principles and contains a number of (legal) initiatives in three main areas, such as equal opportunities and access to the labour market, fair working conditions, and adequate and sustainable social protection.

In this paper, the research methodology consisted in the analysis of EU documents concerning the EU policy in the field of activities aimed at reducing social inequalities, and consequently minimizing threats to health safety and raising the standards of health policy. The paper collected and analysed international reports, the latest documents and publications available in the electronic database of the European Union, OECD, Eurostat, Eurobarometer of the European Parliament and research commissioned by the European Parliamentary Research Service.

\section{ELIMINATION OF SOCIAL INEQUALITIES IN THE EUROPEAN UNION POLICY}

In 2013, the European Commission published a report on health inequalities according to which there are fewer and fewer differences in life expectancy and infant mortality in the EU Member States.

The gap between the longest and shortest life expectancy in the EU-27 countries was reduced by $17 \%$ between 2007 and 2011 for men and by $4 \%$ between 2006 and 2011 for women. In terms of infant mortality, the gap between the EU countries with the highest and lowest index decreased from 15.2 to 7.3 per 1,000 live births between 
2001 and 2011. The average infant mortality rate in the EU also declined in this period, from 5.7 to 3.9 per 1,000 live births.

(http://europa.eu/rapid/press-release_IP-13-823_pl.htm.).

According to the report, health inequalities between individual countries, regions and social groups are as follows:

- according to this report, Sweden has the highest average life expectancy for men, at 79.9 years - almost by 12 years more than the member state with the lowest value (68.1 years).

- The life expectancy of women, on the other hand, is the highest in France, at 85.7 years, i.e. by 8 years more than in the member state with the lowest female life expectancy (77.8 years).

- In the case of healthy life years in men, the difference between the lowest and highest values in the EU is 19 years. In the case of women, it is almost similarly high (18.4 years).

- The difference between life expectancy at birth between the most disadvantaged and the least disadvantaged regions was 13.4 years in 2010 for men and 10.6 years for women.

- In the same year, there were seven regions in the EU where infant mortality rates exceeded 10 in 1,000 live births. It was 2.5 times higher than the EU average of $4.1 / 1,000$.

- In 2010, the difference in the estimated life expectancy of 30-year-old men between the most and the least educated groups ranged from around 3 to 17 years in different Member States. In the case of women, the difference was slightly smaller - from 1 to 9 years (http://europa.eu/rapid/press-release_IP-13823_en.htm).

These disproportions result primarily from differences in everyday life conditions and from factors such as unemployment, income or education, which determine the prevalence of risky health problems such as obesity.

The report also pointed to the progress in the implementation of the EU Solidarity in Health programme and highlights the need for further actions at local, national and EU levels. The consistent activities aim both to support policy development in EU countries and to increase the contribution of EU policies to reducing health inequalities. The main driver of these efforts is the ongoing joint action planned for 2020.

One of the tools is the health investment document adopted in February 2013 to synchronise national reforms with the EU health policy for sustainable health systems, investing in human health and elimination of health inequalities (Warchoł , 2017).

The European Union also faces ageing population as a problem. Europeans have fewer and fewer children. In the 1960s, there were 2 live births per woman, while the current fertility rate in the EU is 1.58 on average. An example is fertility rate in Ireland and Portugal, which used to be above 3 and today is below 2. The increasing life expectancy combined with falling fertility rates leads to a significant ageing of the population. There are currently more people aged over 65 in the EU than children under 14. By 2050, almost a third of

Europeans will be at least 65 years old. Currently, less than one fifth of the population belongs to this age group. Compared to the rest of the world, Europeans, with a median age of 45 years, will be the oldest society in the world by 2030 (https://ec. 
europa.eu/commission/sites/beta-political/files/reflection-paper-social-dimensioneurope_en.pdf).

The State of Health in the EU, which aims to provide policy-makers, health professionals and interest groups with knowledge about health and health systems in EU countries and comparable data, has also been in place for two years now at the initiative of the European Commission. A cycle of these studies has been developed jointly with the Organisation for Economic Co-operation and Development (OECD) and the European Observatory on Health Systems and Policies.

The sources and methods underlying these data are available in the Eurostat and OECD health databases. Some additional data also come from the Institute for Health Metrics and Evaluation (IHME), the European Centre for Disease Prevention and Control (ECDC), the Health Behaviour in School-aged Children (HBSC) and the World Health Organisation (WHO), as well as from other national sources (https://ec.europa.eu/health/state/summary_pl).

Research commissioned by the State of Health in the EU concerning Poland shows that despite an improvement in the health status of the Polish population, life expectancy is still below the EU average. In Poland, life expectancy at birth was 77.5 in 2015 , which means an increase by nearly 4 years since 2000 . However, this is still three years below the EU mean, but represents a slight narrowing of the gap compared to 2000. In Poland, there is a gap of eight years between men and women in terms of life expectancy at birth (73.5 and 81.6 years, respectively) compared to an average gap of 5.4 years in other EU countries. There is also a significant difference depending on the socio-economic status: On average, Poles with higher education live almost 10 years longer than those who have not completed secondary education. The increase in life expectancy in Poland after 2000 is mostly due to a decrease in the mortality rate after the age of 65 . Polish women at this age can expect to survive another 20.1 years (compared to 17.5 years in 2000). In the case of Polish men, this number is 15.7 years (compared to 13.5 years in 2000). Not all of these years are lived in good health. At the age of 65 , Polish men can expect that they will live about half of remaining years of life (7.6 years) without disability, while a woman can expect to live without disability only two fifths of the remaining years of life (8.4 years).

More than a third of the health burden in Poland can be attributed to behavioural risk factors. Despite a decline in the number of smokers in the last decade, more than one in five adults continues to be addicted to cigarettes. Alcohol consumption has also increased since 2000. One in six adults reports regular excessive abuse. The situation with regard to obesity indices is also unfavourable as they have also increased and are now above the EU average.

Health care expenditure in Poland is one of the lowest in the EU. In 2015, health expenditure amounted to EUR 1,259 per capita or 6.3\% of GDP, compared to an EU average of EUR 2,781 (9.9\%). Public resources account for $72 \%$ of the expenditure, which is below the EU average (79\%). Direct expenditure is relatively high $(22 \%)$, raising concerns about accessibility (https://ec.europa.eu/health /state /country_ profiles_en).

\section{THE EXPECTATIONS OF COMMUNITY CITIZENS WITH REGARD TO EUROPEAN UNION ACTIVITIES TO REDUCE SOCIAL INEQUALITIES}

The EU's Eurobarometer survey was conducted between 2014 and 2019 and concerned the behaviour of Europeans two years before the elections to the 
European Parliament in May/June 2019. The aim of this survey was to record the reactions of Europeans to important developments in the world in recent months, to identify their perceptions and expectations of European Union activities in relevant fields. The survey was conducted by Kantar Public in $28 \mathrm{EU}$ countries among 27,901 citizens (http://www.europarl.europa.eu/news/pl/headlines/society/20170608STO7691 2 /polityka-spoleczna-europejczycy-oczekuja-od-ue-wiecej-dzialan).

Surveys show that Europeans expect more from the EU on issues relating to combating unemployment, social safety and the promotion of health and gender equality. $78 \%$ of the respondents count on more effective combating unemployment by the European Union. The March 2017 Eurobarometer survey showed that $63 \%$ of the respondents consider current community activities in this field as insufficient. The percentage of dissatisfied people decreased by 6 percentage points compared to 2016.

In contrast, $70 \%$ of respondents want greater EU activity to improve health and social safety issues, which is by 7 percentage points more than in the previous year. Furthermore, $49 \%$ emphasized that what the community is currently doing is not enough. In the field of equal treatment between women and men, $65 \%$ of respondents think that the Union should do more. This is by $10 \%$ more than in 2016 . Interestingly, as many as $84 \%$ of respondents believe that social inequalities in their countries represent a serious concern and $64 \%$ of them stated that in five years, this problem will become more important.

$78 \%$ of respondents expect the European Union to combat unemployment more effectively (http://www.europarl.europa.eu/news/pl/headlines/society/20170608STO 76912/polityka-spoleczna-europejczycy-oczekuja-od-ue-wiecej-dzialan ).

\section{CONCLUSION}

Health safety is more and more often included in European safety and health programmes. The European Union, together with the EU member states, is pursuing a broad work programme in this area. In these programmes, the European Union's policies also take into account new challenges, such as huge migratory flows, the economic crisis or austerity policies, which affect the everyday lives of EU citizens. Therefore, cooperation of member states with the EU opens up an important opportunity to work together on health inequalities and the fundamental social determinants of health, with the overall aim of improving the health and well-being of EU citizens and achieving greater equality of health effects across all social groups by focusing on the socio-economic determinants of health inequalities related to health and lifestyles.

This joint action is aimed in particular to identify a policy framework with a set of actions and recommendations for adoption and implementation at national, regional and local levels; develop better policies for improving monitoring, management, implementation and evaluation; implement good practices and facilitate exchange and learning; and identify success factors, barriers and challenges and ways to overcome them.

\section{REFERENCES}

Bsoul- Kopowska M., 2019, Strategic goals of the European Union In managing health security., R. Ulewicz, R.R. Nikolić, ( ed.). System safety: Human Technical - Facility - Environment, wyd. De Gruyter, Częstochowa. 
Centrum Systemów Informatycznych Ochrony Zdrowia, Fundusze unijne 2007 2013, http://www.csioz.gov.pl/wiw/index.php/fundusze-unijne-2007-2013.html ,

Dotacje Unijne, Priorytet XII Bezpieczeństwo zdrowotne i poprawa efektywności systemu ochrony zdrowia, http://www.dotacja-unijna.com/unijne,link-24,podlink37.html,Program+Operacyjny+Infrastruktura+i+Srodowisko,Bezpieczenstwo+zdrow otne+i+poprawa+efektywnosci+systemu+ochrony+zdrowia ,

Europejski Fundusz Społeczny w Ministerstwie Pracy i Polityki Społecznej, Działanie 2.3.1 - opracowanie kompleksowych programów zdrowotnych, http://www. kapitalludzki.gov.pl/o-programie/priorytet-ii/dzialanie-23/poddzialanie-231/,

Europejski Fundusz Społeczny w Ministerstwie Pracy i Polityki Społecznej, Działanie 2.3.2 - Doskonalenie zawodowe kadr medycznych, http://www.kapitalludzki.gov.pl /o-programie/priorytet-ii/dzialanie-23/poddzialanie-232/ ,

Fundusze strukturalne, Program Operacyjny Kapitał Ludzki 2007 - 2013, http://www.funduszestrukturalne.gov.pl/NSS/programy/krajowe/pokl/ ,

Ruszkowski J., 2010. Zwiększenie bezpieczeństwa zdrowotnego, ekspertyza wykonana na zlecenie Ministerstwa Rozwoju Regionalnego. Warszawa.

Sytnik-Czetwertyński J., Cianciara D., 2016. The individual face to face with public health: a conflict of interests or a conflict of conditions? Journal of Education, Health and Sport, 6(2):223-237, elSSN 2391-8306. DOI http://dx.doi.org/10.5281 zzenodo.46590

Ślusarz B, Mitela-Grzybek A., 2013. Bezpieczeństwo zdrowotne mieszkańców Unii Europejskiej ze szczególnym uwzględnieniem nowej perspektywy finansowej na przykładzie województwa lubuskiego. Przegląd Naukowo-Metodyczny. Edukacja dla Bezpieczeństwa, 4, 269-278, p. 271

Warchoł M., 2017. Dotacje unijne w latach 2007-2013 a system ochrony zdrowia w Polsce, Journal of Education, Health and Sport, 7 (5), 401-409.

Wrześniewska - Wal I., 2016, Zdrowie publiczne w regulacjach Unii Europejskiej. Postępy Nauk Medycznych., XXIX (5), 322-326.

https://europa.eu/european-union/topics/health_pl ( dostęp: 03.03.2019)

http://eur-lex.europa.eu/legal-content/PL/TXT/?uri=CELEX\%3A12016E168

(dostęp:12.03.2019)

http://europa.eu/rapid/press-release_IP-13-823_pl.htm ( dostęp: 23.03.2019)

https://ec.europa.eu/health/social ( dostęp: 23.03.2019)

https://ec.europa.eu/health/state/summary_pl ( dostęp: 25.03.2019

https://ec.europa.eu/health/state/country_profiles_pl ( dostęp: 25.03.2019

http://www.europarl.europa.eu/news/pl/headlines/society/20170608STO76912/polityk a-spoleczna-europejczycy-oczekuja-od-ue-wiecej-dzialan ( dostęp: 23.03.2019)

https://ec.europa.eu/commission/sites/beta-political/files/reflection-paper-socialdimension-europe_pl.pdf ( dostęp: 25.03.2019) 